\title{
Genetic variation in thioredoxin interacting protein (TXNIP) is associated with hypertriglyceridaemia and blood pressure in diabetes mellitus
}

Citation for published version (APA):

van Greevenbroek, M. M., Vermeulen, V. M., Feskens, E. J., Evelo, C. T., Kruijshoop, M., Hoebee, B., van der Kallen, C. J., \& de Bruin, T. W. (2007). Genetic variation in thioredoxin interacting protein (TXNIP) is associated with hypertriglyceridaemia and blood pressure in diabetes mellitus. Diabetic Medicine, 24(5), 498-504. https://doi.org/10.1111/j.1464-5491.2007.02109.x

Document status and date:

Published: 01/01/2007

DOI:

10.1111/j.1464-5491.2007.02109.x

Document Version:

Publisher's PDF, also known as Version of record

Document license:

Taverne

Please check the document version of this publication:

- A submitted manuscript is the version of the article upon submission and before peer-review. There can be important differences between the submitted version and the official published version of record.

People interested in the research are advised to contact the author for the final version of the publication, or visit the DOI to the publisher's website.

- The final author version and the galley proof are versions of the publication after peer review.

- The final published version features the final layout of the paper including the volume, issue and page numbers.

Link to publication

\footnotetext{
General rights rights.

- You may freely distribute the URL identifying the publication in the public portal. please follow below link for the End User Agreement:

www.umlib.nl/taverne-license

Take down policy

If you believe that this document breaches copyright please contact us at:

repository@maastrichtuniversity.nl

providing details and we will investigate your claim.
}

Copyright and moral rights for the publications made accessible in the public portal are retained by the authors and/or other copyright owners and it is a condition of accessing publications that users recognise and abide by the legal requirements associated with these

- Users may download and print one copy of any publication from the public portal for the purpose of private study or research.

- You may not further distribute the material or use it for any profit-making activity or commercial gain

If the publication is distributed under the terms of Article $25 \mathrm{fa}$ of the Dutch Copyright Act, indicated by the "Taverne" license above, 


\title{
Genetic variation in thioredoxin interacting protein (TXNIP) is associated with hypertriglyceridaemia and blood pressure in diabetes mellitus
}

\author{
M. M. J. van Greevenbroek, V. M. M-J. Vermeulen, E. J. M. Feskens*†, C. T. Evelo‡, \\ M. Kruijshoop, B. Hoebee§, C. J. H. van der Kallen and T. W. A. de Bruin
}

Laboratory of Molecular Metabolism and Endocrinology, Cardiovascular Research Institute Maastricht (Carim) and Department of Internal Medicine, Maastricht University, Maastricht, ${ }^{*}$ Centre for Nutrition and Health, National Institute for Public Health and the Environment, Bilthoven, tDivision of Human Nutrition, Section Nutrition and Epidemiology, Wageningen University, Wageningen, ¥BiGCat Bioinformatics, University of Maastricht and Technical University Eindhoven, Maastricht and §Laboratory of Toxicology, Pathology and Genetics, National Institute for Public Health and the Environment, Bilthoven, the Netherlands

Accepted 9 October 2006

\begin{abstract}
Aims Thioredoxin interacting protein (TXNIP) is an attractive candidate gene for diabetes or diabetic dyslipidaemia, since TXNIP is the strongest glucoseresponsive gene in pancreatic B-cells, TXNIP deficiency in a mouse model is associated with hyperlipidaemia and TXNIP is located in the $1 \mathrm{q} 21-1 \mathrm{q} 23$ chromosomal Type 2 diabetes mellitus (DM) locus. We set out to investigate whether metabolic effects of TXNIP that were previously reported in a murine model are also relevant in human Type $2 \mathrm{DM}$.
\end{abstract}

Methods The frequency distribution of a 3' UTR single nucleotide polymorphism (SNP) in TXNIP was investigated in subjects with normal glucose tolerance (NGT; $n=379$ ), impaired glucose tolerance (IGT; $n=228$ ) and Type 2 DM $(n=230)$. Metabolic data were used to determine the effect of this SNP on parameters associated with lipid and glucose metabolism.

Results The frequency of the TXNIP variation did not differ between groups, but within the group of diabetic subjects, carriers of the TXNIP-T variant had 1.6-fold higher triglyceride concentrations $(P=0.015 ; n=136)$ and a $5.5-\mathrm{mmHg}$ higher diastolic blood pressure $(P=0.02 ; n=212)$ than homozygous carriers of the common C-allele, whereas in non-diabetic subjects fasting glucose was $0.26 \mathrm{mmol} / \mathrm{l}$ lower $(P=0.002 ; n=478)$ in carriers of the T-allele. Moreover, a significant interaction between plasma glucose concentrations and TXNIP polymorphism on plasma triglycerides was observed $(P=0.012 ; n=544)$.

Conclusion This is the first report to implicate TXNIP in a human disorder of energy metabolism, Type 2 diabetes. The effect of TXNIP on triglycerides is influenced by plasma glucose concentrations, suggesting that the biological relevance of TXNIP variations may be particularly relevant in recurrent episodes of hyperglycaemia.

Diabet. Med. 24, 498-504 (2007)

Keywords diastolic blood pressure, genetic predisposition, thioredoxin interacting protein (TXNIP), triglyceride, Type 2 diabetes mellitus.

Abbreviations apo, apolipoprotein; BMI, body mass index; DBP, diastolic blood pressure; FCHL, familial combined hyperlipidaemia; GCNF, germ cell nuclear factor; HOMA, homeostasis model assessment; IGT, impaired glucose tolerance; NGT, normal glucose tolerance; PCR, polymerase chain reaction; SBP, systolic blood pressure; SNP, single nucleotide polymorphism; T2DM, Type 2 diabetes mellitus; TRX, thioredoxin; TXNIP, thioredoxin interacting protein; USF-1, upstream stimulatory factor 1; VEGF, vascular endothelial growth factor 


\section{Introduction}

In several human populations, the 1q21-1q23 chromosomal area has been implicated in Type 2 diabetes mellitus (T2DM) [1] as well as in familial combined hyperlipidaemia (FCHL) [2]. In general, both T2DM and FCHL are believed to be determined by a disease-predisposing genetic background in concert with environmental risk factors such as obesity [3]. Moreover, subjects with T2DM and FCHL express common metabolic abnormalities, i.e. high plasma concentrations of fatty acids and/or triglycerides and insulin resistance. HcB19 mice are phenotypically characterized by inherited hyperlipidaemia, especially hypertriglyceridaemia, and hepatic steatosis [4], two conditions that are common in both T2DM and FCHL [5,6]. Therefore, data obtained with this recently described mouse model of inherited hyperlipidaemia may be useful for gene discovery in these related human diseases.

The gene defect in these hyperlipidaemic HcB19 mice is a truncation in thioredoxin interacting protein (TXNIP) [7], which is located in a chromosomal region that is syntenic with the human 1q21-23 locus. TXNIP was initially proposed as a candidate gene for FCHL [7], but was later excluded for this disease in different populations [8-10]. More recently, upstream stimulatory factor 1 (USF-1) has been identified as the most likely causal gene for hyperlipidaemia in FCHL in this chromosomal locus [8]. Although the 1q21-23 locus is also implicated in T2DM and hypertriglyceridaemia is present in up to $50 \%$ of White T2DM patients [11], recent evidence strongly suggests that USF-1 may not be a very relevant gene in diabetes [12,13]. For these and additional reasons (discussed below), we hypothesized that the TXNIP gene is involved in the development of hypertriglyceridaemia in diabetes.

Several indirect lines of evidence support the hypothesis that variations in TXNIP activity may affect an individual's susceptibility to development of diabetes. First, TXNIP regulates cellular thioredoxin (TRX) activity [14] and targeted expression of TRX in the pancreas protects B-cells against autoimmuneand streptozotocin-induced diabetes [15]. Second, Shalev et al. [16] have recently shown that TXNIP is the strongest glucoseresponsive gene expressed in cultured human pancreatic $\beta$-cells. Lastly, increased insulin concentrations have been reported in TXNIP-deficient HcB19 mice [17], although this was not the case in the original $\mathrm{HcB} 19$ report [4]. These functional data on the roles of TXNIP and thioredoxin, combined with the chromosomal localization of TXNIP on 1q21-23 and the hypertriglyceridaemic effect of the truncation in HcB19 mice, support the hypothesis that variations in the TXNIP gene may affect susceptibility to T2DM or to hypertriglyceridaemia in T2DM.

It was the objective of the present study to analyse associations between a polymorphism in the $3^{\prime}$ UTR of the human TXNIP gene and several aspects of human diabetes in a population enriched in risk factors for T2DM. First, we established whether TXNIP variations could influence the risk of Type 2 diabetes in humans. Next, the effects of the TXNIP variant on plasma lipid variables were determined in healthy subjects and diabetes patients. Finally, the effects of TXNIP variation on other phenotypic characteristics of Type 2 diabetes were analysed.

\section{Methods}

\section{Study design}

The hypothesis that the TXNIP gene is involved in the development of hypertriglyceridaemia in diabetes was investigated in the CODAM (COhortstudy on Diabetes and Atherosclerosis Maastricht; 574 subjects) population, extended with 270 subjects collected by the National Institute of Public Health (RIVM) according to exactly the same criteria [18,19]. Assignment of the normal glucose tolerance (NGT; $n=379$ ), impaired glucose tolerance (IGT; $n=228)$ or T2DM $(n=230)$ status was done on the basis of an oral glucose tolerance test according to the 1999 World Health Organization criteria [20]. In the majority of the NGT, IGT and T2DM subjects, the following plasma parameters were determined using standard laboratory techniques [18]: apolipoprotein (apo) A and apoB, total and high-density lipoprotein cholesterol, triglycerides, glucose, insulin, free fatty acids, C-reactive protein. Urinary albumin concentrations and anthropomorphic markers such as waist circumference, height, weight, waist-hip ratio, body mass index (BMI) and blood pressure were also determined [21]. ApoA and apoB were determined in serum by auto analyser (Hitachi 912) using a Roche kit (Roche Diagnostics, Almere, the Netherlands). Homeostasis model assessment (HOMA-IR) was used to assess insulin resistance [22].

Participants provided informed consent and the studies were approved by local ethics committees. General characteristics of the groups with different glucose tolerance states are presented in Table 1.

\section{Single nucleotide polymorphism analysis in TXNIP intron 7}

TXNIP is a very small gene, spanning a genomic region of $<4000$ base pairs. The 3' UTR sequence of human TXNIP mRNA consists of 1307 nucleotides followed by a poly A tail (http://www.ensembl.org; v40, August 2006). The single nucleotide polymorphism (SNP) rs\#7211 is located in the $3^{\prime}$ UTR, 402 base-pairs downstream of the TXNIP coding region (http: //ncbi.nlm.nih.gov/SNP/). The C-allele (major allele) contains a restriction enzyme site for SnaB1 that is absent in the T-allele (minor allele). This particular SNP was chosen since it was a confirmed SNP with an acceptable reported average allele frequency of $25.5 \% \mathrm{~T}$ and $74.5 \% \mathrm{C}$ (http://www.ncbi.nlm. nih.gov). DNA was prepared from peripheral blood mononuclear cells (QiaAmp DNA blood mini kit; Qiagen, Hilden, Germany). Polymerase chain reaction (PCR) amplification was performed using the following primer set: 5'TGTTTGTTGGATGGG TTTAA-3' (forward primer) and 5'CCACATGAAACCAACCA TC-3' (backward primer). The amplification reactions contained $12.5 \mathrm{pmol}$ of each primer, $0.75 \mathrm{U}$ of Taq polymerase and $1.5 \mathrm{~mm} \mathrm{MgCl}$ in a final volume of $12.5 \mu \mathrm{l}$. An annealing temperature of $57^{\circ} \mathrm{C}$ was used and the reaction was cycled for 35 repeats. Digestion of the PCR products with $5 \mathrm{U}$ of SnaB1 (New England Biolabs, Ipswich, MA, USA) resulted 
Table 1 General characteristics of the study population

\begin{tabular}{|c|c|c|c|c|}
\hline \multirow[b]{2}{*}{ Glucose tolerance status } & \multicolumn{2}{|c|}{ Non-diabetic subjects } & \multirow{2}{*}{$\frac{\text { Diabetic subjects }}{\text { T2DM }}$} & \multirow{2}{*}{$\frac{\text { ANOVA/Kruskal-Wallis }}{P \text {-value }}$} \\
\hline & NGT & IGT & & \\
\hline Age (years)* & $58 \pm 7$ & $58 \pm 7$ & $60 \pm 7$ & 0.002 \\
\hline BMI $\left(\mathrm{kg} / \mathrm{m}^{2}\right)^{*}$ & $27.5 \pm 3.8$ & $29.3 \pm 4.2$ & $30.5 \pm 4.3$ & $<0.001$ \\
\hline Percent male* & 59 & 61 & 68 & NS \\
\hline Fasting glucose $(\mathrm{mmol} / \mathrm{l})^{*}$ & $5.3 \pm 0.5$ & $5.9 \pm 0.6$ & $7.8 \pm 1.8$ & \\
\hline Insulin $(\mu \mathrm{U} / \mathrm{ml})^{*}$ & $7.2(5.8-9.9)$ & $9.3(6.4-13.9)$ & $12.0(8.4-18.2)$ & \\
\hline HOMA-IR* & $1.7(1.3-2.3)$ & $2.3(1.6-3.7)$ & $4.2(2.7-6.3)$ & \\
\hline ApoB $(\mathrm{g} / \mathrm{ml}) *$ & $1.1 \pm 0.2$ & $1.2 \pm 0.2$ & $1.1 \pm 0.2$ & NS \\
\hline Cholesterol $(\mathrm{mmol} / \mathrm{l})$ & $5.3 \pm 0.9$ & $5.6 \pm 1.0$ & $5.4 \pm 1.2$ & $<0.001$ \\
\hline Triglycerides $(\mathrm{mmol} / \mathrm{l})^{*}$ & $1.2(0.9-1.7)$ & $1.6(1.1-2.2)$ & $1.8(1.2-2.4)$ & $<0.001$ \\
\hline Free fatty acids $(\mathrm{mmol} / \mathrm{l})^{*}$ & $0.48 \pm 0.16$ & $0.55 \pm 0.19$ & $0.60 \pm 0.21$ & $<0.001$ \\
\hline HDL-cholesterol $(\mathrm{mmol} / \mathrm{l}) *$ & $1.3 \pm 0.3$ & $1.2 \pm 0.3$ & $1.1 \pm 0.3$ & $<0.001$ \\
\hline $\operatorname{ApoA}(\mathrm{g} / \mathrm{ml})^{*}$ & $1.5 \pm 0.2$ & $1.5 \pm 0.2$ & $1.4 \pm 0.2$ & 0.002 \\
\hline Diastolic BP (mmHg)* & $79.1 \pm 9.0$ & $82.4 \pm 10.3$ & $84.6 \pm 9.3$ & $<0.001$ \\
\hline Systolic BP $(\mathrm{mmHg})^{*}$ & $128.0 \pm 17.0$ & $133.0 \pm 18.4$ & $139.8 \pm 18.1$ & $<0.001$ \\
\hline
\end{tabular}

in 889- and 184-bp fragments for the C-allele and 1073 bp for the T-allele. Restriction fragments were separated on a $1.5 \%$ agarose gel and visualized with ethidium bromide. Each time the assay was performed, DNA from a known CC and a known CT individual was included as a positive control (TT DNA was not available).

\section{Statistical analysis}

Presence of Gaussian distribution was analysed for all variables. Variables not having a Gaussian distribution were log transformed. Normally distributed data are presented as mean $\pm \mathrm{SD}$ and differences are assessed by Student's $t$-test/ANOVA; skewed variables are presented as median (interquartile range) and differences are assessed by Mann-Whitney $U$-test/Kruskal-Wallis. No correction for multiple testing was applied since the choice of the variables was largely based on the physiological data available in the TXNIP-deficient mouse model. Using our current knowledge of the allele frequency of the T-allele (see Results), the number of subjects in our analyses provided us with $80 \%$ power to detect a statistically significant effect of the TXNIP gene when the difference between carriers and noncarriers was $0.3 \mathrm{mmol} / \mathrm{l}$ for triglycerides, $0.4 \mathrm{mmol} / \mathrm{l}$ for glucose or $5 \mathrm{mmHg}$ for diastolic blood pressure (DBP) (Quanto version 1.1 [23]). For these calculations we used data from a control population representative of Dutch subjects of similar age to our currently used populations, i.e. the spouse control subjects from our study on FCHL [21]. Thirty-two subjects had not stopped their lipid-lowering medication prior to the blood collection and were excluded from the analyses which included lipid parameters. Differences in metabolic parameters were adjusted for age, gender, BMI and site of data sampling, as indicated using linear regression analysis. In linear regression analyses all standardized residuals were $>-3$ and $<3$, and normal distribution of the residuals was verified. All analyses were done using SPSS 9.0 (SPSS Inc., Chicago, IL, USA).

\section{Results}

\section{TXNIP polymorphism and prevalence of diabetes}

The allele distributions of the TXNIP C/T polymorphism (rs\#2711) were consistent with Hardy-Weinberg equilibrium in all groups. We have analysed this polymorphism in more than 1800 subjects (control, diabetic and hyperlipidaemic subjects from different populations, all White). The mean frequency of carriers of the minor T-allele was $7.8 \%$ (range $5.3-13.9 \%$ ) in different control and patient populations, frequencies which are consistent with data currently reported for populations of White descent (http://www.ensembl.org).

In the population reported here, the frequency of T-allele carriers was not different $\left(\chi^{2} ; P=0.4\right)$ between groups with different glucose tolerance status, i.e. $7.4 \%$ in NGT ( $n=28$ of 379$), 10.5 \%$ in IGT $(n=23$ of 219$)$ and $9.3 \%$ in T2DM subjects $(n=20$ of 215$)$. No homozygous carriers of the TXNIP minor allele (TT) were identified.

\section{Effects of the TXNIP genotype in individuals with different glucose tolerance status}

\section{Blood pressure}

Data on TXNIP genotype and blood pressure were available for 812 subjects (of the 837 included in the study; see also Tables 1 
Table 2 Characteristics of carriers and non-carriers of the TXNIP-T allele in NGT, IGT and Type 2 diabetes subjects

\begin{tabular}{|c|c|c|c|c|c|c|}
\hline & \multicolumn{4}{|c|}{ Non- diabetic subjects } & \multirow{2}{*}{\multicolumn{2}{|c|}{$\begin{array}{l}\text { Diabetic subjects } \\
\text { T2DM }\end{array}$}} \\
\hline & \multicolumn{2}{|l|}{ NGT } & \multicolumn{2}{|l|}{ IGT } & & \\
\hline & TXNIP-CC & TXNIP-CT & TXNIP-CC & TXNIP-CT & TXNIP-CC & TXNIP-CT \\
\hline Cholesterol $(\mathrm{mmol} / \mathrm{l}) \dagger$ & $5.3 \pm 0.9$ & $5.3 \pm 1.0$ & $5.5 \pm 1.0$ & $5.7 \pm 0.9$ & $5.4 \pm 1.2$ & $5.6 \pm 0.8$ \\
\hline Triglycerides $(\mathrm{mmol} / \mathrm{l}) \dagger$ & $1.2(0.9-1.7)$ & $1.3(1.1-1.5)$ & $1.6(1.1-2.0)$ & $1.8(1.4-2.5)$ & $1.6(1.2-2.3)$ & $2.0(1.6-5.0)^{*}$ \\
\hline Fasting glucose $(\mathrm{mmol} / \mathrm{l}) \dagger$ & $5.3 \pm 0.5$ & $5.0 \pm 0.5^{* *}$ & $5.9 \pm 0.7$ & $5.6 \pm 0.5$ & $7.8 \pm 1.8$ & $7.9 \pm 2.2$ \\
\hline HOMA-IR $\dagger$ & $1.7(1.4-2.3)$ & $1.7(1.9-4.8)$ & $2.3(1.6-3.6)$ & $2.5(1.9-4.8)$ & $4.3(2.7-6.4)$ & $3.3(2.3-5.3)$ \\
\hline Diastolic BP $(\mathrm{mmHg}) \dagger$ & $79.2 \pm 9.1$ & $78.6 \pm 7.8$ & $82.1 \pm 10.7$ & $84.5 \pm 10.8$ & $84.0 \pm 9.5$ & $89.1 \pm 8.6^{* *}$ \\
\hline Systolic BP (mmHg)† & $128.2 \pm 17.0$ & $127.5 \pm 17.7$ & $132.4 \pm 18.4$ & $139.1 \pm 19.2$ & $139.1 \pm 17.8$ & $143.5 \pm 20.9$ \\
\hline $\begin{array}{l}\text { The data presented are unac } \\
\text { †Data on blood pressure we } \\
\text { Type } 2 \text { diabetes mellitus (T2 } \\
\text { (TXNIP-CC/TXNIP-CT). F } \\
\text { in } 268 / 16 \text { NGT, } 111 / 15 \text { IG } \\
\text { groups with different glucos } \\
\text { Whitney } U \text {-test). } P \text {-values a }\end{array}$ & $\begin{array}{l}\text { ved mean } \pm \text { SD o } \\
\text { vailable in } 350 \\
\text { 1) (TXNIP-CC/ } \\
\text { g triglycerides, } \\
\text { d } 127 / 9 \text { T2DM } \\
\text { lerance status ( } \\
\text { ted for age, gen }\end{array}$ & $\begin{array}{l}\text { nedian (interqua } \\
\text { normal glucose } \\
\text { XNIP-CT). Fasti } \\
\text { lolesterol and ho } \\
\text { TXNIP-CC/TXN } \\
\text { GT, IGT, T2DM } \\
\text { r, sampling site }\end{array}$ & $\begin{array}{l}\text { range) values. } \\
\text { erance (NGT), } \\
\text { lucose was avai } \\
\text { stasis model ass } \\
\text { CT). Statistical } \\
P<0.05, * P< \\
\text { body mass inde }\end{array}$ & $\begin{array}{l}5 / 23 \text { impaired g } \\
\text { le in } 302 / 22 \mathrm{~N} \\
\text { sment of insulir } \\
\text { ferences betwee }\end{array}$ & $\begin{array}{l}\text { ose tolerance (IG } \\
138 / 16 \text { IGT and } \\
\text { sistance (HOMA } \\
\text { XNIP-CC and T } \\
\text { values); Student' } \\
\text { rovided in the te }\end{array}$ & $\begin{array}{l}\text { and } 195 / 20 \\
48 / 12 \text { T2DM } \\
\text { ) were available } \\
\text { NIP-CT within } \\
\text {-test/Mann- }\end{array}$ \\
\hline
\end{tabular}

and 2). DBP was $5.5 \mathrm{mmHg}$ higher in T2DM subjects with the TXNIP-CT genotype than in CC individuals $[P=0.013 ; 95 \%$ confidence interval (CI) 1.2, 9.9, adjusted for age, gender and sampling site], but there was no effect in NGT and IGT subjects. Additional adjustment for BMI did not substantially change these data $(P=0.02 ; 95 \%$ CI $0.8,9.5 \mathrm{mmHg})$. Systolic blood pressure (SBP) did not differ significantly between diabetic carriers of the TXNIP-T allele $(143.5 \pm 20.9 \mathrm{mmHg})$ and homozygous diabetic carriers of the major C-allele (139.1 $\pm 17.8 \mathrm{mmHg}$; Student's $t$-test $P=0.21$, adjusted for age, gender, BMI and sampling site). Urinary albumin concentrations were also higher in diabetic carriers of the TXNIP-T allele [16.1 mg/l (10.2-24.9), median (interquartile range); $n=7$ ] than in diabetic TXNIP-CC subjects [6.0 mg/l (3.15-13.05); $n=101, P=0.019]$.

\section{Fasting triglycerides}

Data on TXNIP genotype and fasting triglycerides were available for a total of 546 subjects (see Tables 1 and 2). Plasma triglyceride concentrations were 1.6-fold higher in diabetic carriers of the TXNIP minor T-allele than in diabetic CC individuals (95\% CI 1.1, 2.3-fold; $P=0.013$, adjusted for age, gender and sampling site). Additional adjustment for BMI did not substantially change these data $(P=0.015 ; 95 \%$ CI 1.1, 2.3). There were no obvious effects of the TXNIP genotype in triglyceride levels in the NGT and IGT subjects.

\section{Indicators of glucose metabolism and insulin resistance}

Data on TXNIP genotype and fasting glucose were available for 638 subjects (see Tables 1 and 2). Fasting glucose was $0.26 \mathrm{mmol} / \mathrm{l}$ lower in NGT subjects with the TXNIP-CT genotype than in CC individuals $(P=0.009 ; 95 \% \mathrm{CI}-0.45$,
-0.063 , adjusted for age, gender and sampling site). Fasting glucose levels were also lower in IGT carriers of the TXNIPCT genotype, but this did not reach statistical significance $(0.25 \mathrm{mmol} / \mathrm{l} ; P=0.12$, adjusted for age, gender and sampling site). Additional adjustment for BMI decreased $P$-values slightly ( $P=0.008$ and $P=0.07$ for NGT and IGT, respectively). Analysis of all non-diabetic subjects combined (i.e. all NGT and IGT subjects), strengthened this relation, resulting in a $0.26 \mathrm{mmol} / \mathrm{l}$ lower fasting glucose in non-diabetic carriers of the T-allele compared with non-diabetic TXNIP-CC individuals $[P=0.002,95 \% \mathrm{CI}-0.42,-0.09$; adjusted for age, gender, BMI, glucose-tolerance-status (NGT of IGT) and sampling site] This effect of the TXNIP polymorphism on glucose was absent in the T2DM subjects $(P>0.8)$. There were no significant effects of the TXNIP polymorphism on HOMA-IR or plasma insulin concentrations in any of the groups.

\section{Interaction of the TXNIP genotype with parameters of glucose homeostasis}

It was recently reported that TXNIP is a highly glucoseresponsive gene in the pancreatic $\beta$-cell [16]. Moreover, Hui et al. [17] have suggested that the hyperlipidaemia in the TXNIP-deficient HcB19 mouse model may, at least in part, be secondary to hyperinsulinaemia. We investigated, using linear regression analysis, whether plasma glucose concentrations per se or, alternatively, presence of insulin resistance or hyperinsulinaemia, interacted with the TXNIP gene polymorphism in the effect on plasma triglyceride levels. There was a significant interaction between fasting plasma glucose concentrations and the TXNIP genotype on plasma triglyceride concentration $[P=0.012$ for the interaction term (TXNIP $\times$ glucose) adjusted for age, gender and BMI; Table 3, $n=544]$. No interaction was observed between plasma insulin 
Table 3 Linear regression model describing the interaction between the effects of fasting glucose concentration and the TXNIP polymorphism on plasma triglyceride concentration

\begin{tabular}{|c|c|c|c|c|c|}
\hline & \multicolumn{5}{|c|}{ All subjects* } \\
\hline & B & Std B & $P$-value & $R^{2}$ & $\begin{array}{l}\text { Overall } \\
P \text {-value }\end{array}$ \\
\hline Constant & -0.149 & & 0.10 & 0.139 & $<0.001$ \\
\hline Age (years) & -0.002 & -0.063 & 0.12 & & \\
\hline Gender $($ male $=0$, female $=1)$ & -0.020 & -0.047 & 0.24 & & \\
\hline Body mass index $\left(\mathrm{kg} / \mathrm{m}^{2}\right)$ & 0.008 & 0.165 & $<0.001$ & & \\
\hline Fasting glucose $(\mathrm{mmol} / \mathrm{l}) \dagger$ & 0.033 & 0.241 & $<0.001$ & & \\
\hline TXNIP genotype $(\mathrm{CC}=0$; $\mathrm{CT}$ or $\mathrm{TT}=1) \dagger$ & 0.072 & 0.091 & 0.025 & & \\
\hline Interaction (TXNIP genotype $\times$ fasting glucose $) \dagger$ & 0.049 & 0.102 & 0.012 & & \\
\hline
\end{tabular}

"Normal glucose tolerance, $n=283$; impaired glucose tolerance, $n=126$, Type 2 diabetes mellitus, $n=135$.

†Centred variables were used to reduce multicollinearity.

concentration or HOMA-IR and the TXNIP polymorphism on plasma triglyceride concentrations [interaction (TXNIP $\times$ insulin), $P=0.9$, interaction (TXNIP $\times$ HOMA-IR), $P=0.3$, adjusted for age, gender, BMI, disease status, TXNIP genotype and insulin/HOMA].

\section{Discussion}

Genetic and metabolic data in the current literature prompted us to investigate whether the TXNIP gene might play a role in human metabolism, and more specifically in the development of human diabetes and/or the hyperlipidaemia associated with diabetes. TXNIP is a highly glucose-responsive gene [16] and a recent report by Minn et al. [24] has shown that glucose directly stimulates TXNIP expression via a carbohydrate response element (CHOre) in the promoter of this gene. The overall frequency of the TXNIP variation did not differ between diabetic and non-diabetic subjects, implying that this polymorphism did not affect the risk of T2DM in these subjects. However, genetic variations in the TXNIP gene did significantly affect several parameters associated with diabetes.

The TXNIP polymorphism influences triglyceride metabolism. Plasma triglyceride concentrations were elevated in diabetic carriers of the TXNIP-T allele, but not in non-diabetic $\mathrm{T}$ carriers. This was confirmed in additional analyses: triglyceride concentrations were influenced by a significant interaction between plasma glucose concentration and the TXNIP polymorphism. This latter aspect is of particular interest because of the previously mentioned regulation of TXNIP expression by glucose [16] and suggests that the biological relevance of TXNIP variations may be particularly important when glycaemic control is inadequate. High plasma glucose concentrations in diabetes reflect insufficient amounts of plasma insulin, which is most likely associated with a relative glucose deficit in the cells and might subsequently compromise TXNIP expression. This effect might be more pronounced, i.e. may have greater metabolic consequences, in carriers of the T-allele. Indeed, hyperglycaemia in diabetes is often associated with hypertriglyceridaemia [25,26]. Interestingly, interaction between TXNIP and plasma glucose concentration on plasma triglyceride could also explain, at least in part, the absence of effect of the TXNIP polymorphisms on hypertriglyceridaemia in FCHL [8-10] that was confirmed in our own FCHL patients (data not shown), because FCHL patients generally remain normoglycaemic, despite insulin resistance and hyperinsulinaemia.

Our data suggest that the potential of an individual to utilize glucose for energy homeostasis, which is altered in diabetes, may interfere with a metabolic effect of the TXNIP polymorphism. The TXNIP-T allele is associated with lower fasting glucose levels in the non-diabetic state, but with hypertriglyceridaemia in diabetic subjects. This is in line with previously reported mouse data. It has been suggested that TXNIP may act as a regulator or switch in fuel utilization, possibly via changes in the cellular redox status [17,27]. Absence of TXNIP in mice induced, among others, an altered hepatic response to nutrient signals [17] and disturbances in the fasting-refeeding transition [27] and, of interest, both these studies reported reduced fasting glucose concentrations in TXNIP-deficient mice.

Our present data are based on the results of one SNP in the 3' UTR of the TXNIP gene, and not all metabolic variables were available for all subjects. In addition, we used a relatively small study population, although the power calculation suggested that we did have acceptable power to detect the differences reported here. A larger study population would possibly also have allowed us to detect more subtle differences. Despite these limitations, it is noteworthy that two of the three variables found to be affected by this TXNIP polymorphism in our human study population, i.e. triglycerides and glucose, match those that were earlier reported in the murine model $[4,7,17,27,28]$. The phenotypic changes associated with the minor TXNIP T-allele in our human subjects were analogous to those reported in the TXNIP-deficient HcB19 mouse model. This suggests that the most likely effect of the TXNIP T-allele is a decreased amount of (functional) TXNIP protein, possibly 
accompanied by higher cellular thioredoxin activity. A possible consequence of a polymorphism in the 3' UTR region of a gene is a change in RNA stability or translation efficiency. The position of rs\#7211 is in the proximal one-third of the 3' UTR, almost 1000 bases away from the poly A tail. Moreover, the region surrounding the SNP is not particularly AU-rich. It is therefore unlikely to influence the stability through influencing the poly A tail. Analysis the human and rat 3' UTR sequence with rVista 2.0/Transfac [29] revealed a conserved binding site covering the SNP for germ cell nuclear factor (GCNF). However, based on the currently known functions of GCNF, which are mainly related to embryonic development and germ cell maturation (as reviewed in [30]), this factor does not appear to be a very plausible candidate for regulation of TXNIP. Therefore, the exact implications of the presence of this particular SNP remain to be established.

The TXNIP-T allele was also associated with higher levels of DBP in the diabetic subjects. Blood pressure had not been previously addressed in the murine model and we had no clear prior expectations of effects of this polymorphism on blood pressure. The association between higher DBP and the presence of the minor TXNIP T-allele was independent of plasma triglyceride concentrations and BMI. As discussed above, the TXNIP-T allele is most likely associated with decreased TXNIP activity and, consequently, with higher cellular thioredoxin activity. An interesting aspect in this regard is that thioredoxin can induce the expression of vascular endothelial growth factor (VEGF) [31]. This reveals a possible pathway via which the TXNIP-T allele may be associated with higher VEGF expression. Increased VEGF concentrations, in turn, have been reported to induce diabetic nephropathy [32,33], which is reflected by, for example, microalbuminuria. It is well known that microalbuminuria is associated with increased blood pressure $[34,35]$. Thus, the presence of the TXNIP-T allele, if associated with lower cellular levels of TXNIP and increased thioredoxin activity, higher VEGF expression and increased microalbuminuria, could potentially explain, at least in part, the increase in DBP observed in the diabetic carriers of the TXNIP-T allele. Although this mechanism is highly speculative, the higher DBP in the diabetic carriers of the TXNIP-T allele we report in our current study was indeed accompanied by significantly increased urinary albumin concentrations, suggesting that renal dysfunction was commoner in these subjects.

In conclusion, we have established that interaction between a genetic variation in the TXNIP gene and fasting plasma glucose affects plasma triglyceride concentrations in human subjects. This suggests that variations in this gene may be particularly relevant in human metabolic disorders with recurrent episodes of poor glycaemic control. Indeed, the 3' UTR polymorphism in TXNIP was specifically associated with hypertriglyceridaemia in human Type 2 diabetic subjects. In addition, an effect on DBP was seen which was independent of plasma triglyceride concentrations. The association of the TXNIP polymorphism with hypertriglyceridaemia and increased blood pressure may potentially contribute to cardiovascular risk in T2DM.

\section{Competing interests}

T.W.A.d.B. is employed by GlaxoSmithKline, a company that manufactures and markets pharmaceuticals related to the treatment of diabetes and its complications.

\section{Acknowledgements}

This work was supported in part by grants from the Netherlands Organization for Scientific Research (940-35-034), the Dutch Diabetes Research Foundation (98.901) and the Netherlands Heart Foundation (2000-198). We thank Arie van Erk for his assistance in the sequence analyses with rVISTA.

\section{References}

1 Elbein S, Hoffman M, Teng K, Leppert M, Hasstedt S. A genome-wide search for type 2 diabetes susceptibility genes in Utah Caucasians. Diabetes 1999; 48: 1175-1182.

2 Pajukanta P, Nuotio I, Terwilliger JD, Porkka KV, Ylitalo K, Pihlajamaki J, et al. Linkage of familial combined hyperlipidaemia to chromosome 1q21-q23. Nat Genet 1998; 18: 369-373.

3 Buse JB, Polonsky KS, Burant CF. Type 2 diabetes mellitus. In Larsen P, Kronenberg H, Melmed S, Polonsky KS eds. Williams Textbook of Endocrinology. Philidelphia: Saunders 2003; 1427-1483.

4 Castellani LW, Weinreb A, Bodnar J, Goto AM, Doolittle M, Mehrabian M, et al. Mapping a gene for combined hyperlipidaemia in a mutant mouse strain. Nat Genet 1998; 18: 374-377.

5 Angelico F, Del Ben M, Conti R, Francioso S, Feole K, Maccioni D, et al. Non-alcoholic fatty liver syndrome: a hepatic consequence of common metabolic diseases. J Gastroenterol Hepatol 2003; 18 : $588-594$

6 de Bruin TWA, Georgieva AM, Brouwers MC, Heitink MV, van der Kallen CJ, van Greevenbroek MM. Radiological evidence of nonalcoholic fatty liver disease in familial combined hyperlipidemia. Am J Med 2004; 116: 847-849.

7 Bodnar JS, Chatterjee A, Castellani LW, Ross DA, Ohmen J, Cavalcoli J, et al. Positional cloning of the combined hyperlipidemia gene Hyplip1. Nat Genet 2003; 30: 110-116.

8 Pajukanta P, Lilja H, Sinsheimer J, Cantor RM, Lusis AJ, Gentile M, et al. Familial combined hyperlipidemia is associated with upstream transcription factor 1 (USF1). Nat Genet 2004; 36: 371-376.

9 Coon H, Singh N, Dunn D, Eckfeldt JH, Province MA, Hopkins PN, et al. TXNIP gene not associated with familial combined hyperlipidemia in the NHLBI Family Heart Study. Atherosclerosis 2004; 174: 357-362.

10 van der Vleuten GM, Hijmans A, Kluijtmans LA, Blom HJ, Utalenhoef AF, de Graaf J. Thioredoxin interacting protein in Dutch families with familial combined hyperlipidemia. Am J Med Genet A 2004; 130: 73-75.

11 Salomaa VV, Tuomilehto J, Jauhiainen M, Korhonen HJ, Stengard J, Uusitupa M, et al. Hypertriglyceridemia in different degrees of glucose intolerance in a Finnish population-based study. Diabetes Care 1992; 15: 657-665.

12 Gibson F, Hercberg S, Froguel P. Common polymorphisms in the USF1 gene are not associated with type 2 diabetes in French Caucasians. Diabetes 2005; 54: 3040-3042.

$13 \mathrm{Ng}$ MC, Miyake K, So WY, Poon EW, Lam VK, Li JK, et al. The linkage and association of the gene encoding upstream stimulatory factor 1 with type 2 diabetes and metabolic syndrome in the Chinese population. Diabetologia 2005; 48: 2018-2024.

14 Nishiyama A, Matsui M, Iwata S, Hirota K, Masutani H, Nakamura H, et al. Identification of thioredoxin-binding protein-2/vitamin D (3) 
up-regulated protein 1 as a negative regulator of thioredoxin function and expression. J Biol Chem 1999; 274: 21645-21650.

15 Hotta M, Tashiro F, Ikegami H, Niwa H, Ogihara T, Yodoi J, et al. Pancreatic beta cell-specific expression of thioredoxin, an antioxidative and antiapoptotic protein, prevents autoimmune and streptozotocininduced diabetes. J Exp Med 1998; 188: 1445-1451.

16 Shalev A, Pise-Masison CA, Radonovich M, Hoffman SC, Hirshberg B, Brady JN, et al. Oligonucleotide microarray analysis of intact human pancreatic islets: identification of glucose-responsive genes and a highly regulated TGFbeta signaling pathway. Endocrinology 2002; 143: 3695-3698.

17 Hui TY, Sheth SS, Diffley JM, Potter DW, Lusis AJ, Attie AD, et al. Mice lacking thioredoxin-interacting protein provide evidence linking cellular redox state to appropriate response to nutritional signals. J Biol Chem 2004; 179: 24387-24393.

18 Kruijshoop M, Feskens EJ, Blaak EE, de Bruin TW. Validation of capillary glucose measurements to detect glucose intolerance or type 2 diabetes mellitus in the general population. Clin Chim Acta 2004; 341: 33-40.

19 van Dam RM, Hoebee B, Seidell JC, Schaap MM, de Bruin TW, Feskens EJ. Common variants in the ATP-sensitive $\mathrm{K}+$ channel genes KCNJ11 (Kir6.2) and ABCC8 (SUR1) in relation to glucose intolerance: population-based studies and meta-analyses. Diabet Med 2005; 22: 590-598.

20 World Health Organization. Definition, diagnosis and classification of diabetes mellitus and its complication. In Report of a WHO Consultation. Part 1: Diagnosis and Classification of Diabetes Mellitus. WHO Technical Report Series. Geneva: WHO 1999: 1-59.

21 Keulen ET, Voors-Pette C, de Bruin TW. Familial dyslipidemic hypertension syndrome: familial combined hyperlipidemia, and the role of abdominal fat mass. Am J Hypertens 2001; 14: 357-363.

22 Bonora E, Targher G, Alberiche M, Bonadonna RC, Saggiani F, Zenere MB, et al. Homeostasis model assessment closely mirrors the glucose clamp technique in the assessment of insulin sensitivity: studies in subjects with various degrees of glucose tolerance and insulin sensitivity. Diabetes Care 2000; 23: 57-63.

23 Gauderman WJ, Morrison JM. Quanto 1.1: A Computer Program for Power and Sample Size Calculations for Genetic-Epidemiology Studies. 2006. Available at http://hydra.usc.edu/gxe.

24 Minn AH, Hafele C, Shalev A. Thioredoxin-interacting protein is stimulated by glucose through a carbohydrate response element and induces beta cell apoptosis. Endocrinology 2005; 146: 23972405.

25 Bruno G, Cavallo-Perin P, Bargero G, Borra M, D’Errico N, Pagano G. Glycaemic control and cardiovascular risk factors in type 2 diabetes: a population-based study. Diabet Med 1998; 15: 304-307.

26 Ostlund RE Jr, Semenkovich CF, Schechtman KB. Quantitative relationship between plasma lipids and glycohemoglobin in type I patients. Longitudinal study of 212 patients. Diabetes Care 1989; 12 : 332-336.

27 Sheth SS, Castellani LW, Chari S, Wagg C, Thipphavong CK, Bodnar JS, et al. Thioredoxin-interacting protein deficiency disrupts the fasting-feeding metabolic transition. J Lipid Res 2005; 46: $123-$ 134.

28 Van Greevenbroek MMJ, Vermeulen V, de Bruin TWA. Identification of novel molecular candidates for fatty liver in the hyperlipidemic mouse model, HcB19. J Lipid Res 2004; 45: 1148-1154.

29 Loots GG, Ovcharenko I. rVISTA 2.0: evolutionary analysis of transcription factor binding sites. Nucl Acids Res 2004; 32: W217W221.

30 Zechel C. The germ cell nuclear factor (GCNF). Mol Reprod Dev 2005; 72: 550-556.

31 Welsh SJ, Bellamy WT, Briehl MM, Powis G. The redox protein thioredoxin-1 (Trx-1) increases hypoxia-inducible factor 1alpha protein expression: Trx-1 overexpression results in increased vascular endothelial growth factor production and enhanced tumor angiogenesis. Cancer Res 2002; 62: 5089-5095.

32 Cha DR, Kang YS, Han SY, Jee YH, Han KH, Han JY, et al. Vascular endothelial growth factor is increased during early stage of diabetic nephropathy in type II diabetic rats. J Endocrinol 2004; 183: $183-$ 94.

33 Asselbergs FW, de Boer RA, Diercks GF, Langeveld B, Tio RA, de Jong PE, et al. Vascular endothelial growth factor: the link between cardiovascular risk factors and microalbuminuria? Int J Cardiol 2004; 93: 211-215.

34 Mogensen CE. Systemic blood pressure and glomerular leakage with particular reference to diabetes and hypertension. J Intern Med 1994; 235: 297-316.

35 Knight EL, Kramer HM, Curhan GC. High-normal blood pressure and microalbuminuria. Am J Kidney Dis 2003; 41: 588-595. 